\title{
Effect of long-term fertilization on free-living nematode community structure in Mollisols
}

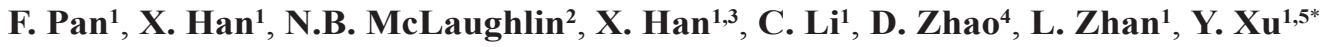 \\ ${ }^{1}$ Key Laboratory of Mollisols Agroecology, National Observation Station of Hailun Agroecology System, \\ Northeast Institute of Geography and Agroecology, Chinese Academy of Sciences, Harbin 150081, \\ China. *Corresponding author: xyll@neigaehrb.ac.cn ${ }^{2}$ Eastern Cereal and Oilseed Research Centre, Science \\ and Technology Branch, Agriculture and Agri-Food Canada, Ottawa, Canada K1A 0C6 ${ }^{3}$ Heilongjiang \\ University, Harbin 150080, China ${ }^{4}$ Horticultural Branch, Heilongjiang Academy of Agricultural Sciences, \\ Harbin 150069, China ${ }^{5}$ Northeast Institute of Geography and Agroecology, Chinese Academy of Sciences, 138 \\ Haping Road, Harbin 150081, China
}

\begin{abstract}
The influence of long-term application of pig manure combined with chemical fertilizer (MCF) or chemical fertilizer (CF) on free-living nematodes was evaluated in this study. The application model of fertilizers lasted 14 years in Mollisols, and treatments included MCF, CF and no fertilizer (NF). A total of 26 free-living nematode genera belonging to seven functional guilds were found in maize fields, and the community structure of free-living nematodes was different in MCF, CF and NF. Pig manure increased the abundance of bacterivores, especially those belonging to c-p1 (Ba1) and c-p2 (Ba2) guilds. Channel index (CI) was higher in NF than in MCF and CF, but enrichment index (EI) was higher in MCF and CF compared to NF. The structure index (SI) was highest in NF among three treatments. Total bacterivores, $\mathrm{Ba} 1$ and $\mathrm{Ba} 2$ guilds were positively correlated to organic $\mathrm{C}$, total $\mathrm{N}$, available $\mathrm{N}$, total $\mathrm{P}$ and available $\mathrm{P}$, but fungivores only had correlation with organic $\mathrm{C}$ and soil moisture. The SI index was negatively related to organic $\mathrm{C}$, total $\mathrm{N}$, available $\mathrm{N}$, total $\mathrm{P}$ and available P. Collectively, these results indicate that the pig manure or chemical fertilizer normally applied to increase soil nutrition also induce negative influence on soil food web structure as reflected from biological aspect, and that soil nematodes can enhance agroecological assessments of changes induced by long-term fertilizer application in maize field in Mollisols.
\end{abstract}

Keywords: Free-living nematodes, food web indices, long-term fertilization, Mollisols, soil physicochemical properties 


\section{Introduction}

Amendments of organic manure or fertilizer are essential for increasing crop productivity, but they also induce environmental changes (Giola et al., 2012; Oloyede, 2012; Liu et al., 2013; Khan et al., 2014). The changes affect soil nematode communities and other soil microorganisms which live in soil and play important roles in nutrient cycling (Fließbach and Mäder, 2000; Yeates, 2003). Soil nematodes are ubiquitous, diverse, abundant, and form one of the dominant belowground communities in agroecosystems (Ritz and Trudgill, 1999). Nematode community attributes such as tropic groups, life history, ecological indices, and food web indices can be combined to form what many researchers consider as ideal bio-indicators for environmental assessment and soil quality assessment (Bongers, 1990; Ferris et al., 2001; Yeates, 2003; Liang et al., 2009).

Soil nematodes are usually assigned to five or eight trophic groups according to their feeding habits (Yeates et al., 1993), and this classification is particularly useful to characterize the positions of nematodes in soil food webs (Moore and de Ruiter, 1991). Free-living nematodes form a large proportion of total soil nematodes, and include bacterivores, fungivores, predators and omnivores. Different trophic groups of free-living nematodes closely correlate to other microorganisms and participate in fundamental ecological processes in soil directly or indirectly, such as decomposition of organic matter and nutrient cycling (Sochová et al., 2006). The population of bacterivores with short generations responds quickly to changes in the food resource (Bongers, 1990). Predators or omnivores can feed on other soil nematodes or other soil microfauna, and they are sensitive to disturbances or recovery of the soil environment (Yeates et al., 1993).
Soil nematode food web indices provide valuable information on soil processes in agroecosystems (Bulluck et al., 2002; Ferris et al., 2001; Papatheodorou et al., 2012). The development of the structural index (SI) provides a significant advance in measure of the number of trophic layers and potential for regulation of opportunists, the enrichment index (EI) successfully detects resource availability, and the channel index (CI) indicates the predominant decomposition pathway of soil organic matter (Ferris et al., 2001). These three indices have been widely used to present the 'structural', 'enrichment' and 'decomposition' conditions of the soil food web under different environments imposed by land use, fertilizer or heavy metal contamination (Ferris et al., 2001; Briar et al., 2007; Pan et al., 2012).

Soil nematode communities and food web indices have been widely applied as ecological tools in various terrestrial ecosystems, especially in agroecosystems (Briar et al., 2007; Liang et al., 2009; Pan et al., 2010). However, the response of soil nematodes to disturbance by fertilizer application was different among different fertilizer regimes, vegetation or soil environments (Villenave et al., 2010; Sohlenius et al., 2011).

In our previous study in the soybean phase of a maizesoybean rotation in the black soil (Mollisols) zone in Northeast China, we found fertilizer application had significant effects on abundance of bacterivores, fungivores and nematode channel ratio (NCR), and that bacterivores were correlated to soil organic C, total $\mathrm{N}$ and available $\mathrm{P}$ (Pan et al., 2010). Combining our previous findings with those of other studies, we hypothesize that the long-term amendments of pig manure or chemical fertilizer would have a significant effect on free-living nematode community structure in a maize field in Mollisols, that free-living nematode 
and soil food web indices would be correlated with soil physicochemical properties. The objectives of the present study were to 1) assess the effect of long-term fertilization on free-living nematode community structure, 2) evaluate effect of long-term fertilization on soil nutrition and food web structure, and 3) determine the correlations among free-living nematodes, soil microorganisms, food web indices and soil physicochemical properties in Mollisols.

\section{Materials and Methods}

A brief overview of experiment and nematode sampling is given here; more details are provided in our previous papers on nematode community structure (Pan et al., 2010) at the same experimental site.

\subsection{Experimental site}

The experiment was conducted on an existing longterm fertilization plots at the National Observation Station of Hailun Agro-ecology System, Heilongjiang province, China $\left(47^{\circ} 26^{\prime} \mathrm{N}, 126^{\circ} 38^{\prime} \mathrm{E}\right)$. The farmland was reclaimed from grassland and has been cultivated about 100 years. No fertilizer was applied to the soil in the region in the first 60 years of planting, livestock manures were applied for the next 20 years, and finally, nitrogen fertilizer was applied in the last 20 years. The soils in the region are typical black soil (Udic Mollisols). Annual precipitation is about 500$600 \mathrm{~mm}$, and cumulative temperature $\left(\geq 10\left({ }^{\circ} \mathrm{C}\right)\right.$ is about 2400-2500 degree-days $\left({ }^{\circ} \mathrm{C}\right)$.

\subsection{Experimental design and sampling}

The long-term fertilization plots were established in 1994. Three fertilizer treatments were included in this study, pig manure combined with chemical $\mathrm{N}$ and $\mathrm{P}$ fertilizer (MCF), chemical $\mathrm{N}$ and $\mathrm{P}$ fertilizer (CF) and no fertilizer (NF). A 3-year rotation of wheat, corn and soybean was applied in the fertilization plots since 1994. No chemical fertilizer or manure was applied in NF. For CF, $150 \mathrm{~kg} \mathrm{~N}^{-1}$ and $32.8 \mathrm{~kg} \mathrm{P} \mathrm{ha}^{-1}$ were applied. The phosphorus fertilizer was in the form of diammonium phosphate. For MCF, pig manure was applied at $30,000 \mathrm{~kg} \mathrm{ha}^{-1}$ in addition to above amounts of chemical fertilizers. Pig manure contained average total N, P and K concentrations of 22.1, 2.6 and 2.4 $\mathrm{g} \mathrm{kg}^{-1}$, respectively. Each treatment of the parent experiment had four replicates and 12 plots were randomly distributed over the experimental field. Each plot occupied $60 \mathrm{~m}^{2}$. The plots were plowed to a depth of about $20 \mathrm{~cm}$ after crop was harvested in autumn. We sampled three of the four plots for each treatment. Soil samples were collected in corn field in June, July, August and September 2007. Ten soil cores, $5 \mathrm{~cm}$ diameter and $20 \mathrm{~cm}$ deep were collected from each plot with a manual soil coring tube. The soil samples from each plot were combined and thoroughly mixed by hand, and plant litter or large stones were removed from the soil samples by passing through a $6 \mathrm{~mm}$ mesh. All soil samples were kept in a refrigerator at $4{ }^{\circ} \mathrm{C}$ for measurements of soil nematode, soil microorganism and soil physicochemical properties.

\subsection{Nematode extraction, identification and classification}

Nematodes were extracted from $100 \mathrm{~g}$ fresh soil by elutriation and centrifugation (Bulluck et al., 2002), and were fixed in a $4 \%$ formaldehyde solution. Then one quarter of each nematode suspension was observed under a Motic microscope $(400 \mathrm{x})$ and each nematode was identified to genus using diagnostic keys. Free-living soil nematodes were assigned to three trophic groups according to Yeates et al. (1993): fungivores, bacterivores and omnivores-predators. 
Soil food web condition of different fertilizer treatments was estimated using food web indices, enrichment index (EI), structure index (SI) and channel index (CI) calculated as described by Ferris et al. (2001). Bacterivores were assigned to four functional guilds, cp-1, cp-2, cp-3 and cp-4 following Bongers (1990).

\subsection{Soil physicochemical property analyses}

Soil samples collected in September 2007 were used for analysis of soil properties. Organic C, total N, soil available $\mathrm{N}$, total $\mathrm{P}$, available $\mathrm{P}$, soil moisture and soil $\mathrm{pH}$ were determined by the methods described in our earlier paper at the same experimental site (Pan et al., 2010).

\subsection{Statistical analyses}

The abundance data of soil nematode were LNtransformed to meet assumptions of normality prior to statistical analyses. Repeated measures analysis of variance was used to test the overall effect of fertilizer and sampling time on abundance of free-living nematodes and food web indices. Separate one-way analyses of variance (ANOVA) were conducted for the effects of fertilizer on free-living nematode and food web indices at each sampling time. Principal component analysis (PCA) was done on the soil physicochemical properties to express the suite of properties with two independent components. Bivariate correlation analysis was used to test the significance of correlations between free-living nematode abundance, food web indices and soil properties. All statistical tests were conducted at a significance level of 0.05 in SPSS version 16.0 statistical software package (SPSS, Chicago, IL).

\section{Results}

3.1. Effect of long-term fertilization on community structure and abundance of free-living nematodes

A total of 26 free-living nematode genera belonging to seven functional guilds were found under the three different fertilizer treatments (Table 1). Among these free-living nematodes, Acrobeloides, Chiloplacus, Protorhabditis and Mesorhabditis were dominant genera in MCF, Protorhabditis and Mesorhabditis were dominant in $\mathrm{CF}$, and Mesorhabditis was dominant in NF.

Fertilizer had significant overall effect on bacterivores but not on fungivores or omnivorespredators (Table 2); sampling time had effect on all these three trophic groups, but fertilizer x sampling time had an effect only on bacterivores. Abundance of bacterivores was always highest in MCF (Figure 1). The abundances of bacterivores, fungivores and omnivores-predators fluctuated with sampling times. Bacterivores and fungivores reached their highest abundance at the end of August, while omnivores-predators showed a general increasing trend over the growing season.

All bacterivore genera except Alaimus and Prismatolaimus belonged to two of the four functional guilds, c-p1 (Ba1) and c-p2 (Ba2) (Table 1). Fertilizer and sampling time both had significant effect on $\mathrm{Ba} 1$ and $\mathrm{Ba} 2$ (Table 2). Abundance of $\mathrm{Ba} 2$ was greater than that of $\mathrm{Ba} 1$ in same treatment for all sampling times. Abundance of Balwas highest in MCF, and lowest in NF. The difference between MCF and CF and NF was greater for $\mathrm{Ba} 1$ than $\mathrm{Ba} 2$ (Figure 2). 

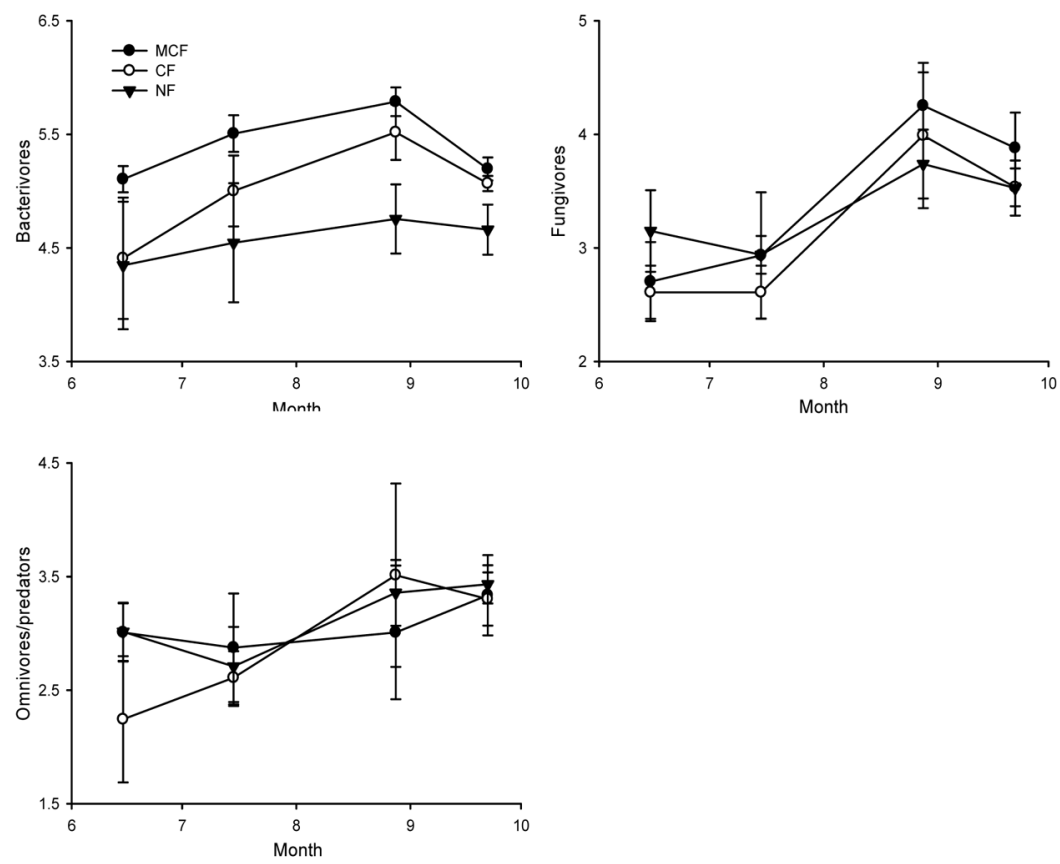

Figure 1. Abundances (LN individuals per $100 \mathrm{~g}$ of dry soil) of free-living nematodes in different trophic groups over maize growing season. MCF: pig manure combined with chemical fertilizer; CF: chemical fertilizer; and NF: no fertilizer. Bars in figure are standard errors.
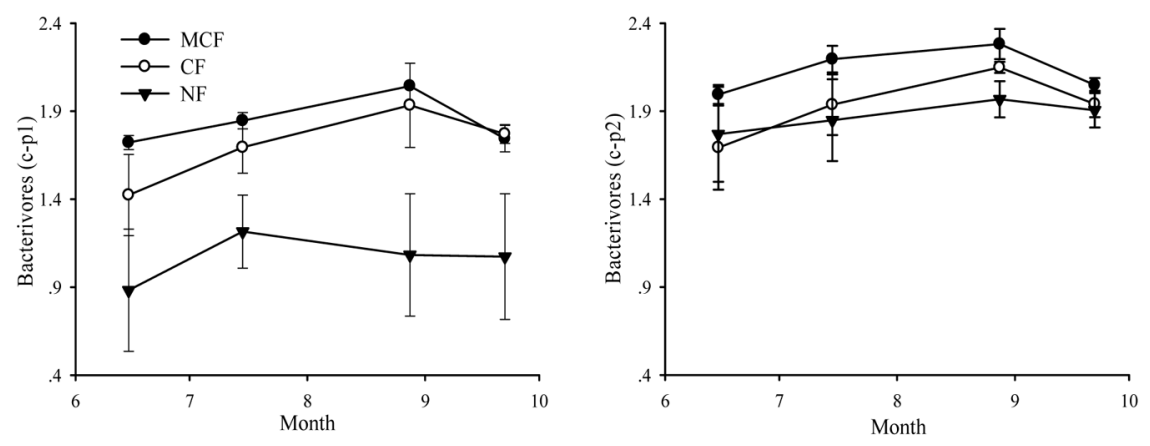

Figure 2. Abundance (LN individuals per $100 \mathrm{~g}$ of dry soil) of bacterivores belonging to c-p1 and c-p2 functional guilds in maize growing season. MCF: pig manure combined with chemical fertilizer; CF: chemical fertilizer; and NF: no fertilizer. Bars in figure are standard errors. 

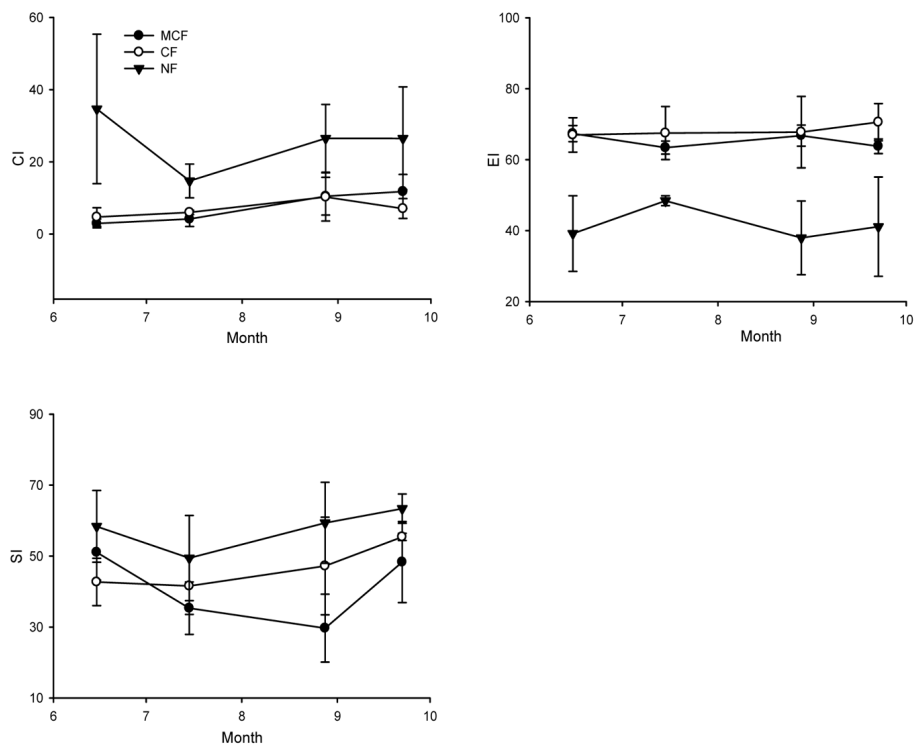

Figure 3. Nematode food web indices in the maize growing season under three fertilizer treatments. CI: channel index, EI: enrichment index, SI: structure index. MCF: pig manure combined with chemical fertilizer; CF: chemical fertilizer; and NF: no fertilizer. Bars in figure are standard errors.

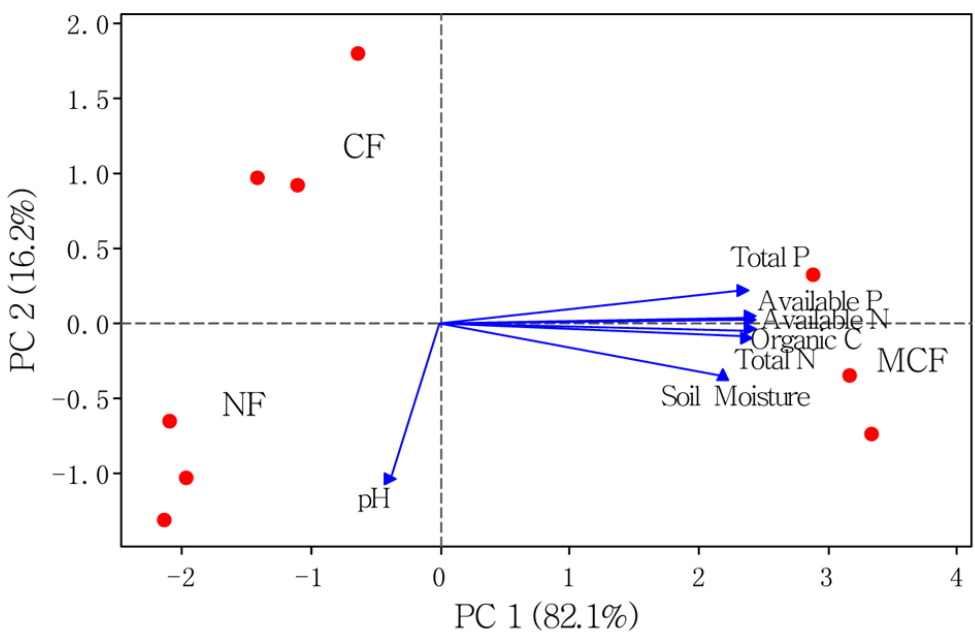

Figure 4. Principal component analysis (PCA) of soil physicochemical properties under different fertilizers. MCF: pig manure combined with chemical fertilizer; CF: chemical fertilizer; and NF: no fertilizer.

(1990). Ba, Fu and Op represent bacterivores, fungivores and omnivores/predators, respectively. Genus was considered as dominant when relative abundance $>5 \%$. 
Table 1. Abundance and proportional contribution (\%) of free-living nematode genera to soil nematodes in maize growing season

\begin{tabular}{|c|c|c|c|c|c|c|c|c|c|}
\hline \multirow[t]{2}{*}{ Family } & \multirow{2}{*}{ Genus } & \multirow{2}{*}{$\begin{array}{l}\mathrm{c}-\mathrm{p} \\
\text { value }\end{array}$} & \multirow{2}{*}{$\begin{array}{l}\text { Trophic } \\
\text { group }\end{array}$} & \multicolumn{3}{|c|}{$\begin{array}{c}\text { Abundance } \\
\text { (individual } 100^{-1} \text { dry soil) }\end{array}$} & \multicolumn{3}{|c|}{$\begin{array}{c}\text { Relative abun- } \\
\text { dance }(\%)\end{array}$} \\
\hline & & & & $\mathrm{MCF}$ & $\mathrm{CF}$ & NF & $\mathrm{MCF}$ & $\mathrm{CF}$ & NF \\
\hline Alaimidae & Alaimus & 4 & $\mathrm{Ba}$ & $0.4 \pm 0.8$ & $0.0 \pm 0.0$ & $0.9 \pm 1.5$ & 0.1 & 0.0 & 0.0 \\
\hline \multirow[t]{6}{*}{ Cephalobidae } & Acrobeles & 2 & $\mathrm{Ba}$ & $16.5 \pm 5.2$ & $4.5 \pm 5.4$ & $10.8 \pm 7.6$ & 3.4 & 1.1 & 1.6 \\
\hline & Acrobeloides & 2 & $\mathrm{Ba}$ & $36.9 \pm 21.5$ & $16.3 \pm 12.2$ & $9.7 \pm 7.5$ & 7.7 & 3.8 & 3.6 \\
\hline & Cephalobus & 2 & $\mathrm{Ba}$ & $19.0 \pm 4.4$ & $17.3 \pm 9.2$ & $4.2 \pm 3.4$ & 4.0 & 4.1 & 2.7 \\
\hline & Cervidellus & 2 & $\mathrm{Ba}$ & $4.9 \pm 3.2$ & $3.5 \pm 4.2$ & $2.1 \pm 3.0$ & 1.0 & 0.8 & 1.2 \\
\hline & Chiloplacus & 2 & $\mathrm{Ba}$ & $39.9 \pm 12.2$ & $17.4 \pm 12.4$ & $31.7 \pm 14.4$ & 8.3 & 4.1 & 3.6 \\
\hline & Eucephalobus & 2 & $\mathrm{Ba}$ & $19.9 \pm 7.5$ & $19.3 \pm 10.9$ & $15.4 \pm 10.2$ & 4.1 & 4.6 & 3.2 \\
\hline \multirow[t]{2}{*}{ Monhysteridae } & Monhystera & 1 & $\mathrm{Ba}$ & $1.4 \pm 2.7$ & $0.0 \pm 0.0$ & $0.0 \pm 0.0$ & 0.3 & 0.0 & 0.0 \\
\hline & Prismatolaimus & 3 & $\mathrm{Ba}$ & $0.4 \pm 0.8$ & $0.0 \pm 0.0$ & $1.2 \pm 1.5$ & 0.1 & 0.0 & 0.0 \\
\hline \multirow[t]{2}{*}{ Plectidae } & Anaplectus & 2 & $\mathrm{Ba}$ & $8.0 \pm 3.7$ & $18.5 \pm 9.9$ & $8.9 \pm 6.7$ & 1.7 & 4.4 & 2.9 \\
\hline & Plectus & 2 & $\mathrm{Ba}$ & $4.2 \pm 2.0$ & $1.7 \pm 3.0$ & $0.4 \pm 0.8$ & 0.9 & 0.4 & 0.9 \\
\hline \multirow[t]{2}{*}{ Rhabditidae } & Mesorhabditis & 1 & $\mathrm{Ba}$ & $44.1 \pm 13.1$ & $40.1 \pm 20.5$ & $8.2 \pm 6.8$ & 9.2 & 9.4 & 6.0 \\
\hline & Protorhabditis & 1 & $\mathrm{Ba}$ & $31.7 \pm 17.5$ & $21.7 \pm 13.4$ & $6.3 \pm 6.6$ & 6.6 & 5.1 & 3.9 \\
\hline Anguinidae & Ditylenchus & 2 & $\mathrm{Fu}$ & $7.2 \pm 9.0$ & $3.9 \pm 4.0$ & $2.6 \pm 3.8$ & 1.5 & 0.9 & 1.2 \\
\hline Aphelenchoididae & Aphelenchoides & 2 & $\mathrm{Fu}$ & $6.2 \pm 6.0$ & $4.2 \pm 4.5$ & $5.4 \pm 3.8$ & 1.3 & 1.0 & 1.3 \\
\hline Aphelenchidae & Aphelenchus & 2 & $\mathrm{Fu}$ & $15.3 \pm 12.2$ & $11.7 \pm 4.8$ & $8.0 \pm 7.3$ & 3.2 & 2.8 & 1.4 \\
\hline Tylenchidae & Filenchus & 2 & $\mathrm{Fu}$ & $11.6 \pm 5.3$ & $11.2 \pm 3.3$ & $13.7 \pm 4.2$ & 2.4 & 2.6 & 1.0 \\
\hline Aporcelaimidae & Aporcelaimus & 5 & Op & $13.5 \pm 1.7$ & $11.0 \pm 5.6$ & $16.9 \pm 4.8$ & 2.8 & 2.6 & 1.6 \\
\hline Dorylaimidae & Mesodorylaimus & 4 & Op & $0.0 \pm 0.0$ & $0.0 \pm 0.0$ & $1.7 \pm 2.3$ & 0.0 & 0.0 & 0.0 \\
\hline Leptonchidae & Doryllium & 4 & $\mathrm{Op}$ & $0.0 \pm 0.0$ & $2.5 \pm 1.5$ & $3.8 \pm 2.8$ & 0.0 & 0.6 & 0.4 \\
\hline Mononchidae & Mononchus & 4 & Op & $0.8 \pm 1.6$ & $0.8 \pm 1.5$ & $0.0 \pm 0.0$ & 0.2 & 0.2 & 0.4 \\
\hline Nordiidae & Enchodelus & 4 & Op & $0.0 \pm 0.0$ & $0.4 \pm 0.7$ & $0.4 \pm 0.8$ & 0.0 & 0.1 & 0.2 \\
\hline \multirow[t]{4}{*}{ Qudsianematidae } & Discolaimium & 4 & Op & $0.4 \pm 0.9$ & $0.0 \pm 0.0$ & $0.0 \pm 0.0$ & 0.1 & 0.0 & 0.0 \\
\hline & Eudorylaimus & 4 & Op & $0.4 \pm 0.8$ & $0.4 \pm 0.7$ & $0.4 \pm 0.8$ & 0.1 & 0.1 & 0.2 \\
\hline & Labronema & 4 & Op & $1.3 \pm 1.7$ & $1.3 \pm 2.2$ & $0.0 \pm 0.0$ & 0.3 & 0.3 & 0.7 \\
\hline & Thorneella & 4 & Op & $6.1 \pm 3.9$ & $6.6 \pm 7.2$ & $0.4 \pm 0.8$ & 1.3 & 1.5 & 2.1 \\
\hline
\end{tabular}

Note: c-p value referred to Bongers 
Table 2. Repeated measures ANOVA for effects of fertilizer, sampling time and interaction of fertilizer x sampling time on freeliving nematodes and food web indices

\begin{tabular}{lrrrrrr}
\hline Nematode trophic & Fertilizer & \multicolumn{2}{c}{ Time } & \multicolumn{3}{c}{ Fertilizer $\times$ time } \\
group and index & F value & df & F value & df & F value & df \\
\hline Bacterivores & $22.5^{* *}$ & 2 & $18.2^{* *}$ & 3 & $3.1^{*}$ & 6 \\
Fungivores & 1.6 & 2 & $13.8^{* *}$ & 3 & 0.9 & 6 \\
Ba1 & $44.0^{* *}$ & 2 & $10.5^{* *}$ & 3 & 2.7 & 6 \\
Ba2 & $12.7^{* *}$ & 2 & $13.5^{* *}$ & 3 & 1.8 & 6 \\
Omnivores-predators & 0.1 & 2 & $4.1^{*}$ & 3 & 1.0 & 6 \\
CI & $35.4^{* *}$ & 2 & 1.3 & 3 & $86.5^{* *}$ & 6 \\
EI & $204.9^{* *}$ & 2 & 0.1 & 3 & 0.57 & 6 \\
SI & $8.7^{*}$ & 2 & $3.9^{*}$ & 3 & 1.3 & 6 \\
\hline
\end{tabular}

Note: $\mathrm{Ba} 1$ and $\mathrm{Ba} 2$ represent bacterivores belonging to c-p1 and c-p2 functional guild. CI, EI and SI mean channel index, enrichment index and structure index, respectively. "**"means significance at the level of $p<0.05$, “**” means significance at the level of $p<0.01$.

\subsection{Food web evaluation}

Fertilizer treatment had significant overall impact on food web indices CI, EI and SI, but sampling time had a significant effect only on SI (Table 2). The value of $\mathrm{CI}$ was higher in NF than in MCF and CF (Fig. 3). Higher value of EI was observed in MCF and $\mathrm{CF}$ compared to NF. There were no significant differences in the value of $\mathrm{CI}$ or EI between MCF and CF. The value of SI was highest in NF among the three treatments, but the difference was not significant at each sampling time. Indices CI and EI had slight fluctuation across sampling time, especially in MCF and $\mathrm{CF}$.

\subsection{Correlations between free-living nematodes and soil properties}

The first two principal components $\mathrm{PC} 1$ and $\mathrm{PC} 2$ explained $98.3 \%$ of the variation of the seven parameter soil properties (Fig. 4). A biplot showed strong positive correlation among organic $\mathrm{C}$, total $\mathrm{N}$, available $\mathrm{N}$, total $\mathrm{P}$, available $\mathrm{P}$ and soil moisture, and they all negatively correlated to soil $\mathrm{pH}$. Organic $\mathrm{C}$, total $\mathrm{N}$, available $\mathrm{N}$ and available $\mathrm{P}$ had a small contribution, total $\mathrm{P}$ and soil moisture had an intermediate contribution, and soil $\mathrm{pH}$ had a large contribution to PC2 (Table 3). The three fertilizer treatments formed three distinct and widely separated clusters on the PC1 vs. PC2 plot (Figure 4) which demonstrates the effect of the long term fertilizer treatments on soil physiochemical properties.

The abundance of bacterivores, $\mathrm{Ba} 1$ and $\mathrm{Ba} 2$ significantly positively correlated to organic $\mathrm{C}$, total $\mathrm{N}$, available $\mathrm{N}$, total $\mathrm{P}$ and available $\mathrm{P}$, and the correlation coefficient of $\mathrm{Ba} 2$ with all soil physicochemical properties except soil moisture were correspondingly stronger than those for Ba1 (Table 4). Fungivores only had significant positive correlation with organic $\mathrm{C}$ and soil moisture. Omnivores-predators had negative 
correlation with all soil properties except $\mathrm{pH}$, but not all of the correlations were significant. SI was negatively correlated to organic $\mathrm{C}$, total $\mathrm{N}$, available
$\mathrm{N}$, total $\mathrm{P}$ and available $\mathrm{P}$, but none of correlations between the other two soil nematode food web indices, $\mathrm{CI}$ and $\mathrm{EI}$ and soil properties were significant.

Table 3. Component score coefficient matrix for first two principal components of soil physicochemical properties

\begin{tabular}{lrr}
\hline Component & PC1 & PC2 \\
\hline Organic C & 0.414 & -0.038 \\
Total N & 0.411 & -0.079 \\
Available N & 0.416 & 0.033 \\
Total P & 0.404 & 0.197 \\
Available P & 0.415 & 0.024 \\
pH & -0.069 & -0.925 \\
Soil Moisture & 0.382 & -0.311 \\
\hline
\end{tabular}

Table 4. Correlation coefficients among free-living nematodes, food web indices and soil properties

\begin{tabular}{|c|c|c|c|c|c|c|c|}
\hline & $\begin{array}{l}\text { Organic } \\
\mathrm{C}\end{array}$ & $\begin{array}{l}\text { Total } \\
\mathrm{N}\end{array}$ & $\begin{array}{l}\text { Available } \\
\mathrm{N}\end{array}$ & Total P & $\begin{array}{l}\text { Available } \\
\text { P }\end{array}$ & $\mathrm{pH}$ & $\begin{array}{l}\text { Soil } \\
\text { moisture }\end{array}$ \\
\hline Bacterivores & $0.76^{*}$ & $0.67 *$ & $0.76^{*}$ & $0.82 * *$ & $0.77^{*}$ & -0.57 & 0.53 \\
\hline $\mathrm{Ba} 1$ & $0.79^{*}$ & $0.74 *$ & $0.8 * *$ & $0.81 * *$ & $0.83 * *$ & -0.12 & $0.85 * *$ \\
\hline $\mathrm{Ba} 2$ & $0.88^{*}$ & $0.86^{* *}$ & $0.90^{* *}$ & $0.91 * *$ & $0.88^{* *}$ & -0.28 & $0.81 * *$ \\
\hline Fungivores & $0.67 *$ & 0.63 & 0.6 & 0.55 & 0.62 & -0.17 & $0.72 *$ \\
\hline Omnivores-predators & -0.15 & -0.19 & -0.11 & -0.16 & -0.06 & 0.07 & -0.04 \\
\hline $\mathrm{CI}$ & -0.32 & -0.26 & -0.37 & -0.47 & -0.37 & 0.43 & -0.11 \\
\hline EI & 0.41 & 0.36 & 0.45 & 0.56 & 0.43 & -0.53 & 0.15 \\
\hline SI & $-0.75^{*}$ & $-0.69 *$ & $-0.69 *$ & $-0.72 *$ & $-0.69 *$ & 0.43 & -0.57 \\
\hline
\end{tabular}

Note: $\mathrm{Ba} 1$ and $\mathrm{Ba} 2$ represent bacterivores belonging to c-p1 and c-p2 functional guilds. CI, EI and SI mean channel index, enrichment index and structure index, respectively. “*”means significance at the level of $p<0.05$, “**” means significance at the level of $p<0.01$. 


\section{Discussion}

Among 26 free-living nematode genera found in this experiment, Acrobeloides, Chiloplacus, Mesorhabditis and Protorhabditis were dominant genera in MCF, and Mesorhabditis and Protorhabditis was the only dominant genus in $\mathrm{CF}$, which indicates that pig manure and chemical fertilizer favored different genera. Ferris et al. (1997) also found Acrobeloides was predominant in the cropping systems with organic inputs. Relative abundance of Mesorhabditis was high in the two treatments with chemical fertilizer, $\mathrm{MCF}$ and $\mathrm{CF}$, which indicates that Mesorhabditis was insensitive to the environmental change induced by fertilizer amendment in Mollisols. Fertilizer treatments had significant effect on bacterivores. The abundance of bacterivores was highest in MCF, intermediate in CF, and lowest in NF. Our results are in agreement with previous findings that bacterivores were more prevalent in organic than conventional chemical fertilizer treatments (Li et al., 2010). Based on the life strategies, four guilds of bacterivores were found, and the abundance of $\mathrm{Ba} 2$ was the largest among of them. The abundances of $\mathrm{Ba} 1$ and $\mathrm{Ba} 2$ were both significantly increased after organic amendments were applied to the soil, and while the abundance of Bal increased more than $\mathrm{Ba} 2, \mathrm{Ba} 1$ was still lower than $\mathrm{Ba}$. $\mathrm{Ba} 1$ and $\mathrm{Ba} 2$ are enrichment-opportunists and general opportunists, respectively, and the abundance of enrichmentopportunists will respond more rapidly than general opportunists when food resources are changed. Our results are in agreement with the findings of Villenave et al. (2004), but contrasts with the results of Liang et al. (2009) who found higher abundance of Bal than $\mathrm{Ba} 2$ under organic amendment condition. The different findings are likely due to different soil environment or nematode genera. Bal was mainly composed by three genera in our study, but it was composed by seven genera in the research of Liang et al. (2009).

We did not find significant effect of long-term pig manure application on fungivores in this study. This is inconsistent with previous findings that organic materials resulted in abundance increase of fungivores (Bulluck et al., 2002; Liang et al., 2009). The different results are likely due to different organic materials, dosage or crops used in the different research.

Most studies found omnivores-predators are sensitive to disturbance of fertilizer or tillage, and need longer time to recover than fungivores and bacterivores (Bulluck et al., 2002). We did not observe effect of fertilizer on omnivores-predators. This result is in agreement with Villenave et al. (2010) who found the effects of organic or fertilizer amendments on composition and abundance of omnivores-predators were minimal. In our experiment, most omnivorespredators belonged to c-p4 guild and only one genus belonged to c-p5 guild, which likely lead to this result because nematodes more sensitive to fertilizer disturbance are generally in a higher c-p guild than in a lower c-p guild (Tenuta and Ferris, 2004).

Fertilizer had significant effect on soil nematode food web indices CI, EI and SI. The index CI was lower in $\mathrm{MCF}$ and $\mathrm{CF}$ than in NF, which suggests pig manure or chemical fertilizer stimulate bacterial decomposition and increase nutrient cycling rate (Ferris et al., 2001). The EI index positively correlated to available resources of food web, and in combination with CI, provides a powerful tool for assessing soil fertility and nutrient availability (Ferris et al., 2001). The amendment of manure or chemical fertilizer resulted in higher EI in MCF and $\mathrm{CF}$ compared to $\mathrm{NF}$, suggesting that more nutrition is available in $\mathrm{MCF}$ and CF than in NF. This result is consistent with previous findings that organic matter (crop cover) or human input enhanced EI (DuPont et al., 2009). The 
SI index can be used to assess the structure of the soil food web from faunal profile, and the higher SI suggests a complex community structure with many linkages in the soil food web (Ferris et al., 2001). The application of pig manure decreased the value of SI in our study. This result is consistent with Villenave et al. (2010) who found lower SI in organic amendment than in un-amended control. This is mainly due to pig manure increasing the abundance of bacterivores, especially those belonging to lower c-p guilds, rather than omnivores-predators; the SI index is primarily determined by higher c-p guilds of bacterivores and omnivores-predators.

The three fertilizer treatments occurred in three clearly separated clusters in the PCA biplot, which means that fertilizer treatment clearly had an effect on soil physicochemical properties measured in this study. Bacterivores, $\mathrm{Ba} 1$ and $\mathrm{Ba} 2$ have positive correlations with organic $\mathrm{C}$, total $\mathrm{N}$, available $\mathrm{N}$, total $\mathrm{P}$ and available $\mathrm{P}$. This is consistent with previous findings that bacterivores positively correlated to $\mathrm{NH}_{4}^{+}$, potentially mineralizable $\mathrm{N}$, organic $\mathrm{C}$ and available P (Sánchez-Moreno et al., 2008; Pan et al., 2010). Our results support previous findings that bacterivores have important contribution to nutrient cycling (Ingham et al., 1985; Fu et al., 2005).

Many studies show that the EI index is correlated with soil nutrition (Sánchez-Moreno et al., 2008), but in our study, correlation of EI with organic C, total $\mathrm{N}$, available $\mathrm{N}$, total $\mathrm{P}$ and available $\mathrm{P}$ was not significant. This is likely due to the different soil type and range of physicochemical properties among the three fertilizer treatments. A negative correlation between SI and organic C, total N, available N, total $\mathrm{P}$ and available $\mathrm{P}$ was observed in our study. Similar results were also found previously where SI was negatively correlated to content of $\mathrm{NH}_{4}-\mathrm{N}$ and $\mathrm{NO}_{3}-\mathrm{N}$ in the soil (Sánchez-Moreno et al., 2006). This might due to relative abundance of bacterivores belonging to higher c-p guilds and omnivores-predators, which are positively related to SI (Ferris et al., 2001) were decreased after amendment of pig manure or chemical fertilizer; as the relative abundance of $\mathrm{Ba} 1$ and $\mathrm{Ba} 2$ are quickly increased in the environment where soil nutrition is enriched.

\section{Conclusions}

The results of this study showed that long-term fertilization had significant effect on free-living nematode community structure in maize phase of a maize-soybean rotation field in Mollisols. Amendment of pig manure or chemical fertilizer increased the abundance of bacterivores, but had little effect on fungivores and omnivores-predators, suggesting that bacterivores are more sensitive to environmental changes caused by amendment of fertilization. Nutrient cycling was promoted by pig manure or chemical fertilizer as indicated by lower value of CI in $\mathrm{MCF}$ or $\mathrm{CF}$ compared to NF. Higher value of EI was found in MCF and $\mathrm{CF}$, indicating amendment of pig manure or chemical fertilizer resulted in more available resource. The application of pig manure decreased the value of SI in our study, indicating that soil food web was disturbed. Bacterivores, Bal and $\mathrm{Ba} 2$ were all positively related to organic $\mathrm{C}$, total $\mathrm{N}$, available $\mathrm{N}$, total $\mathrm{P}$ and available $\mathrm{P}$. A negative correlation between SI and soil physiochemical properties (organic $\mathrm{C}$, total $\mathrm{N}$, available $\mathrm{N}$, total $\mathrm{P}$ and available $\mathrm{P}$ ) was observed, implying that the pig manure or chemical fertilizer may induce negative influence on soil food web structure reflected from biological aspect. The relationships among the nematode indices, fertilizer treatments, and soil properties illustrate that soil nematodes can provide insights in agroecological assessments of changes induced by long-term fertilizer application in maize field in Mollisols. 


\section{Acknowledgements}

This research was supported by The National Natural Science Foundation of China (3100025), Fund of Harbin Science and Technology Bureau (RC2011QN002054) and Key Laboratory Fund of Mollisols Agroecology, Northeast Institute of Geography and Agroecology, Chinese Academy of Sciences (2011ZKHT-06). We thank the staff in National Observation Station of Hailun Agroecology System for field management and help in soil sampling.

\section{References}

Bongers, T. 1990. The maturity index: an ecological measure of environmental disturbance based on nematode species composition. Oecologia. 83, 14-19.

Briar, S.S., Grewal, P.S., Somasekhar, N., Stinner, D., Miller, S.A. 2007. Soil nematode community, organic matter, microbial biomass and nitrogen dynamics in field plots transitioning from conventional to organic management. Appl. Soil Ecol. 37, 256-266.

Bulluck, L.R., Barker, K.R., Ristaino, J.B. 2002. Influences of organic and synthetic soil fertility amendments on nematode trophic groups and community dynamics under tomatoes. Appl. Soil Ecol. 21, 233-250.

DuPont, S.T., Ferris, H., Horn, M.N. 2009. Effects of cover crop quality and quantity on nematodebased soil food webs and nutrient cycling. Appl. Soil Ecol. 41, 157-167.

Ferris, H., Bongers, T., de Geode, R.G.M. 2001. A framework for soil food web diagnostics: extension of the nematode faunal analysis concept. Appl. Soil Ecol. 18, 13-29.
Ferris, H., Venette, R.C., Lau, S.S. 1997. Population energetics of bacterial-feeding nematodes: carbon and nitrogen budgets. Soil Biol. Biochem. 29, 1183-1194.

Fließbach, A., Mäder, P. 2000. Microbial biomass and size-density fractions differ between soils of organic and conventional agricultural systems. Soil Biol. Biochem. 32, 757-768.

Fu, S., Ferris, H., Brown, D., Plant, R. 2005. Does positive feedback effect of nematodes on the biomass and activity of their bacteria prey vary with nematode species and population size? Soil Biol. Biochem. 37, 1979-1987.

Giola, P., Basso, B., Pruneddu, G., Giunta, F., Jones, J.W. 2012. Impact of manure and slurry applications on soil nitrate in a maize-triticale rotation: Field study and long term simulation analysis. Eur. J. Agron. 38, 43-53.

Hussey, R.S., Roncadori, R.W. 1981. Influence of Aphelenchus Avenae on vesicular-arbuscular endomycorrhizal growth response in cotton. J. Nematol. 13, 48-52.

Ingham, R.E., Trofymow, J.A., Ingham, E.R., Coleman, D.C. 1985. Interactions of bacteria, fungi, and their nematode grazers: effects on nutrient cycling and plant growth. Ecol. Monogr. $55,119-140$.

Khan, I., Zaman, M., Khan, M.J., Iqbal, M., Babar, M.N. 2014. How to improve yield and quality of potat oes: effects of two rates of urea $\mathrm{N}$, urease inhibitor and Cytozyme nutritional program. J. Soil Sci. Plant Nutr. 14, 268-276.

Li, Q., Jiang, Y., Liang, W., Lou, Y., Zhang, E., Liang, C. 2010. Long-term effect of fertility management on the soil nematode community in vegetable production under greenhouse conditions. Appl. Soil Ecol. 46, 111-118. 
Liang, W., Lou, Y.L., Li, Q., Zhong, S., Zhang, X., Wang, J. 2009. Nematode faunal response to longterm application of nitrogen fertilizer and organic manure in Northeast China. Soil Biol. Biochem. $41,883-890$.

Liu, C.A., Li, F.R., Zhou, L.M., Zhang, R.H., Jia, Y., Lin, S.L., Wang, L.J., Siddique, K.H.M., Li, F.M. 2013. Effect of organic manure and fertilizer on soil water and crop yields in newly-built terraces with loess soils in a semi-arid environment. Agr. Water Manage. 117, 123-132.

Moore, J.C., de Ruiter, P.C. 1991. Temporal and spatial heterogeneity of trophic interactions within below-ground food webs. Agric. Ecosyst. Environ. 34, 371-397.

Oloyede, F.M. 2012. Growth, yield and antioxidant profile of pumpkin (Cucurbita epo L.) leafy vegetable as affected by NPK compound fertilizer. J. Soil Sci. Plant Nutr. 12, 379-387.

Pan, F., McLaughlin, Neil B., Yu, Q., Xue, A.G., Xu, Y., Han, X., Li, C., Zhao, D. 2010. Responses of soil nematode community structure to different long-term fertilizer strategies in the soybean phase of a soybean-wheat-corn rotation. Eur. J. Soil Biol. 46, 105-111.

Papatheodorou, E.M., Kordatos, H., Kouseras, T., Monokrousos, N., Menkissoglu-Spiroudi, U., Diamantopoulos, J., Stamou, G.P., Argyropoulou, M.D. 2012. Differential responses of structural and functional aspects of soil microbes and nematodes to abiotic and biotic modifications of the soil environment. Appl. Soil Ecol. 61, 26-33.

Ritz, K., Trudgill, D.L. 1999. Utility of nematode community analysis as an integrated measure of the functional state of soils: perspectives and challenges. Plant Soil. 212, 1-11.

Sánchez-Moreno, S., Minoshima, H., Ferris, H., Jackson, L.E. 2006. Linking soil properties and nematode community composition: effects of soil management on soil food webs. Nematol. 8, 703-715.

Sánchez-Moreno, S., Smukler, S., Ferris, H., O 'Geen, A.T., Jackson, L.E. 2008. Nematode diversity, food web condition, and chemical and physical properties in different soil habitats of an organic farm. Biol. Fertil. Soils. 44, 727-744.

Sochová, I., Hofman, J., Holoubek, I. 2006. Using nematodes in soil ecotoxicology. Environ. Int. 32, 374-383.

Sohlenius, B., Boström, S., Viketoft, M. 2011. Effects of plant species and plant diversity on soil nematodes - a field experiment on grassland run for seven years. Nematol. 17, 115-131.

Tenuta, M., Ferris, H. 2004. Sensitivity of nematode life-history groups to ions and osmotic tensions of nitrogenous solutions. J. Nematol. 36, 85-94.

Villenave, C., Ekschmitt, K., Nazaret, S., Bongers, T. 2004. Interactions between nematodes and microbial communities in a tropical soil following manipulation of the soil food web. Soil Biol. Biochem. 36, 2033-2043.

Villenave, C., Saj, S., Pablo, A., Sall, S., Djigal, D., Chotte, J., Bonzi, M. 2010. Influence of longterm organic and mineral fertilization on soil nematofauna when growing Sorghum bicolor in Burkina Faso. Biol. Fertil. Soils. 46, 659-670.

Yeates, G.W. 2003. Nematodes as soil indicators: functional and biodiversity aspects. Biol. Fertil. Soils. 37, 199-210.

Yeates, G.W., Bongers, T., de Goede, R.G.M., Freckman, D.W., Georgieva, S.S. 1993. Feeding habitats in soil nematode families and genera - an outline for soil ecologists. J. Nematol. 25, 315331. 